International Journal of
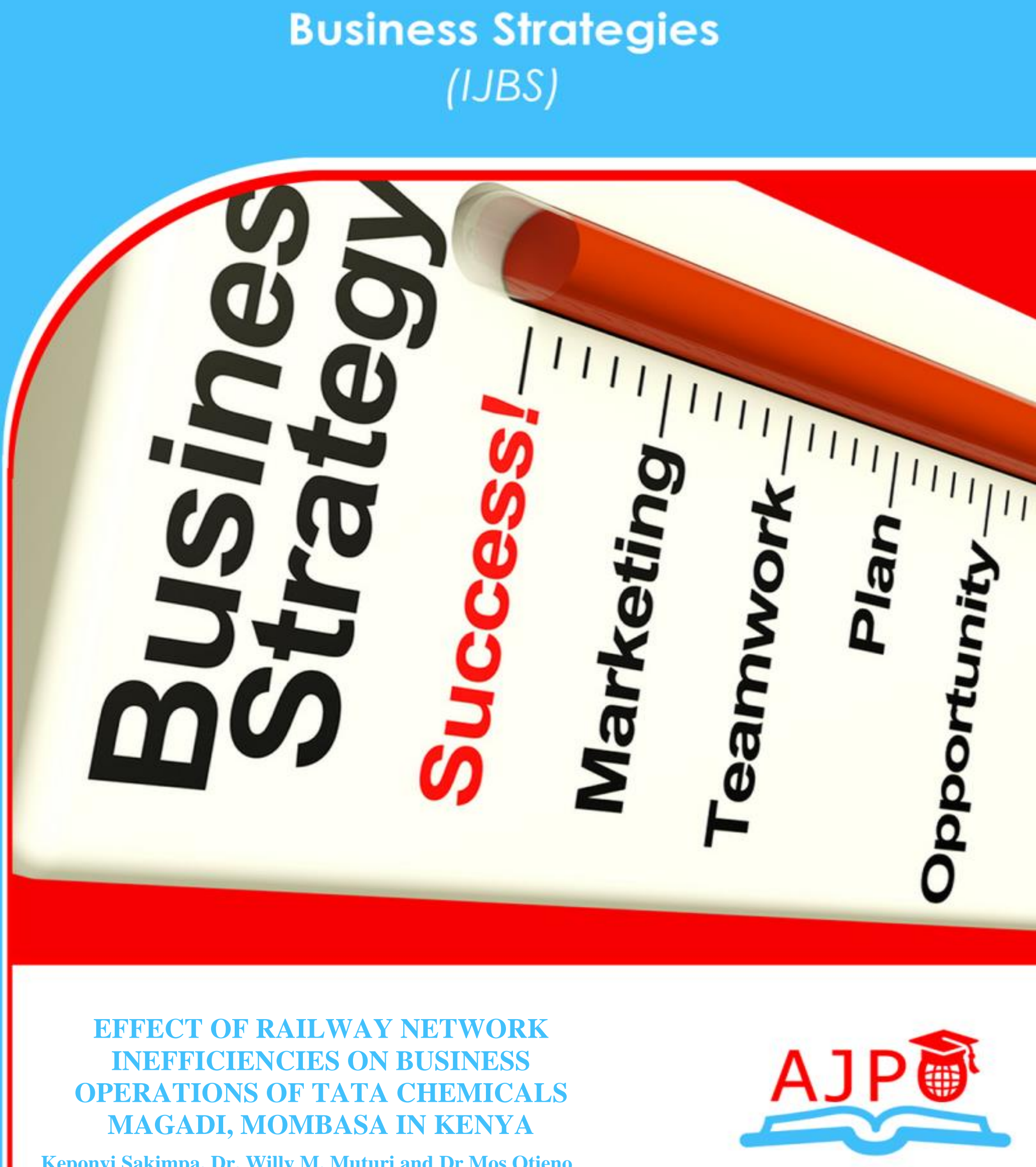

Keponyi Sakimpa, Dr. Willy M. Muturi and Dr Mos Otieno 


\title{
EFFECT OF RAILWAY NETWORK INEFFICIENCIES ON BUSINESS OPERATIONS OF TATA CHEMICALS MAGADI, MOMBASA IN KENYA
}

\author{
$1 *$ Keponyi Sakimpa \\ 1*Post graduate student, Jomo Kenyatta University of Agriculture and Technology \\ *Corresponding Author's Email: fksakimpa@yahoo.com \\ ${ }^{2}$ Dr. Willy M. Muturi \\ Lecturer, Jomo Kenyatta University of Agriculture and Technology \\ ${ }^{3}$ Dr Mos Otieno \\ Lecturer, Jomo Kenyatta University of Agriculture and Technology
}

\begin{abstract}
Purpose: The purpose of this study was to investigate the effect of railway network inefficiencies on business operations of Tata chemicals Magadi, Mombasa in Kenya.

Methodology: This study adopted a descriptive survey design. The target population of this study was the 450 employees of TATA Chemical Magadi Ltd. The study used a sample of 135 employees. The study employed stratified random sampling to identify the 135 respondents. The strata were those of top management, middle management/supervisors and non-managerial employees. Primary data was used to gather information by use of questionnaires. Information was sorted, coded and input into the statistical package for social sciences (SPSS 20) for production of descriptive and inferential statistics.

Results: Results on the analysis of variance showed that the overall model was statistically significant and that the independent variables were good predictors of performance. This was supported by an F statistic of 71.69 and the reported p value (0.000) which was less than the conventional probability of 0.05 significance level. Descriptive results indicated that inefficiencies of Kenya Railway Corporation greatly affect production targets, customer satisfaction, sales targets and equipment utilization in Tata chemicals Magadi Ltd which in turn affects the performance of the company.

Unique contribution to theory, practice and policy: The government should allocate additional annual budget to the Kenya Railways Corporation to provide efficient means of transporting freight between cities and towns. Additionally, management of Tata Chemicals Magadi Ltd should exercise stronger leadership to enhance long term planning and disaster management to avoid loss to customers and manage its efficiency.
\end{abstract}

Key words: Inefficiencies, business operations, Chemicals 


\subsection{INTRODUCTION}

\subsection{Background of the Study}

Railway efficiency is an important topic worldwide for transportation in fiscally strained governments and companies operating in competitive markets. On the one hand, railways are under pressure to keep costs low, often because of market pressures or because of the unavailability of public funds as a result of competing national priorities. On the other hand, increases in railway usage for passenger and freight have occurred after decades of decline, which necessitates additional investment in track infrastructure and rolling stock. Under pressure to reduce costs while improving rail's level of service and expanding rail capacity, railways and governments continue to look for ways to improve efficiency (Congressional Research Service, 2007).

The principal service freight railroads offer is movement of goods from an origin to a destination. Railroad capacity directly affects their ability to provide this service in a timely, reliable and economical manner. The amount of capacity railroads provide is a complicated financial decision. Insufficient capacity increases travel times, which increases operating cost and reduces service quality and reliability thereby reducing demand for some commodities and hence revenue (Weatherford et al., 2008). On the other hand, building and maintaining excess capacity is inefficient use of resources. It can weaken the profitability of a railroad and discourage outside investment. Since excess capacity serves to improve railroad service and reliability, capacity is ultimately a function of a shipper's willingness to pay for a required level of service. Consequently, without consideration of economics, the concept of capacity is meaningless (Congressional Research Service, 2007).

Transportation, its role in mobility and accessibility is a reliable indicator of development. Transportation is the applicable principals to the planning, functional design, operational and management of facilities for any mode of transport in order to provide for the safe, rapid, comfortable, convenient, economical and environmentally compatible movement of goods and people. Efficient means of transportation stimulates economic development by increasing the mobility of workers commuting from one place to the other, customers travelling to and from services areas, and products being transported between producers and consumers (Pittman, 2007).

Therefore, any improvements which decrease transportation costs and increase safety may, in turn, stimulate more economic development by creating a better environment to conduct business. Hence, good transportation has both direct and indirect benefits. Direct benefits are realized through lowering the transport costs of users of the transportation network. Direct user benefits are reductions in travel times and fuel consumption, increased reliability, and increased safety in the movement of people and goods. Indirect benefits from good means of transportation may include the expansion of existing businesses due to the reduced transport costs resulting in greater profitability and/or increased market share and easier entry to business. In addition, economic activity may expand as these growing businesses in turn demand more raw materials and finished items from their suppliers. The end result is that the growth of retail and service businesses is enhanced as employees spend their extra incomes (USA Transport Department, 1994). 


\subsection{Problem Statement}

Rail transport system has been touted as the engine of economic development due to its obvious advantages over road transport especially where freight transport is concerned. Specifically, the Kenyan railway transport system has been earmarked as one of the flagship projects in the achievement of Vision 2030. The current Kenyan government also realizes that the rail system may hold the key to delivery of the myriad promises given to the populace. However, the problem is that the railway network in Kenya is inefficient. The inefficiency of the Kenya railway system has had a negative impact on the business operation of corporations which need its service. Not only has this situation cascaded to the micro, small and large firms, it has also dampened the overall business climate. Therefore, the problem of railway inefficiency is a matter that requires urgent policy solutions.

Tata chemicals Ltd operations depends significantly on the freight transport services of the Kenya railways. Tata chemicals Ltd is a mining company that requires the transport of Soda Ash to the port and the delivery of inputs (for instances, mining machines) from the port to the mining area. The efficiency with which this is done is crucial for the achievement of equipment utilization, productivity, customer satisfaction and sales targets. The current state of inefficiency by Kenya railways in providing this crucial service may have detrimental effects on the business operation so Tata Chemicals.

\subsection{Objectives}

The general objective of this study was to determine the effect of railway network inefficiencies on business operations of Tata chemicals Magadi, Mombasa in Kenya.

\subsection{LITERATURE REVIEW}

\subsection{Theoretical Framework}

\subsubsection{Theory of Supply Chain Management}

The connections and nodes in a Supply Chain achieve functions that contribute to the value of the goods transporting through the chain and thus its achievement. Any connection that does not carry out well reduces the overall effectiveness of the whole Supply Chain. The notion of Supply Chain management as used in many research is usually linked with the globalization of producing and the penchant for manufacturers to source their inputs planetary, which necessitates management of profitable ways of regulating worldwide flows of inputs or outputs. The principal focus of market competition in such situations is not only between goods, but between the Supply Chains delivering the goods. As competition in international markets is progressively dependent upon the of arrival time of goods as well as their quality, coordination between suppliers and distributors has become an important characteristic of the Supply Chain. As the customer satisfaction is a crucial benchmark of the success of the Supply Chain, effective management of the linking processes is crucial (Trkman, Stemberger and Jaklic, 2005).

Additionally, market uncertainty necessitates Supply Chains to be easily flexible to changes in the situation of trade. Such flexibility in supply requires effective Supply Chain Management. According to Grant, Lambert, Stock and Ellram (2006), Supply Chain management refers to 
corporate business processes integration from end users through suppliers that provide information, goods, and services that add value for customers.

Supply chain can be summed up as a series of interconnected activities which are concerned with planning, coordinating and controlling materials, parts and finished products from supplier to customer (Lourenco, 2001). The key success of SCM will rely on the incorporation of the activities of the supply chain, meaning cooperation, information sharing and organization throughout the entire supply chain.

\subsubsection{Internal Improvement Theory}

The internal improvement theory is based on the rationale that ISO 9001 certification brings benefits through greater quality awareness among employees (e.g. BSI, 2000), and increased productivity and efficiency (e.g.RAB, 2000; Reed, Lemak, \& Montgomery, 1996). In other words, ISO 9001 certification seems helpful for companies seeking to improve the quality of their internal business processes. ISO 9001 certification is frequently regarded as the stepping stone to achieving total quality in the entire organization (Quazi, Chang \& Chan, 2002). The drivers of quality-related improvements in a firm's internal business processes are quality consciousness, productivity and efficiency.

Quality-conscious employees understand the importance of producing high-quality output and are capable of executing the operations with that objective in mind. ISO 9001:2008 facilitates this objective by providing guidelines for developing a quality system and the process of acquiring certification impose a certain level of discipline on an organization (Carr, Mak, \& Needham, 1997). Consequently, a company accredited with ISO 9001:2008 is dedicated to maintaining a high-quality environment. Hence, workers would experience fewer problems on the job and consequently increase their motivation and job satisfaction that ultimately manifests in better financial performance.

Productivity and efficiency relate to the rate at which goods and services above minimum satisfactory levels can be delivered to customers. Throughput rate and similar measures of productivity and efficiency increase when employees are aware of quality objectives, and when they are motivated and share common strategic visions. Marquardt (1992) provides evidence consistent with this view. Given the improvements in productivity and efficiency following certification, it is inferred that ISO 9001 certification reaps cost savings by eliminating nonvalue-adding activities, reducing scrap, rework, and warranty claims.

In summary, the internal improvement theory suggests ISO 9001:2008 certifications would improve internal business processes such that production becomes lean and costs decline. Scorecard framework suggest the motivation for ISO 9001:2008 certification could be either internal or external or both.

\subsubsection{External Improvement Theory}

Although internal quality improvements are imperative, companies cannot ignore the needs and responses from the market (Lisiecka, 1999). After all, the purpose of a company is to maintain and increase profits and its survival is contingent on its ability to satisfy customers and sustain competitive advantage (Carr et al., 1997). In other words, a company's improvement must not be 
observable only from inside the organization; its external business partners should also be able to recognize the change and its quality.

While the pursuit for ISO 9001 accreditation may reflect an organization's strategic intent to be quality-focused, research indicates that the driving force could essentially be customers' expectations and contractual requirements (e.g., Brown \& Van der Wiele, 1995; Rayner \& Porter, 1991). Companies stamped with the quality logo increase customer confidence and help speed up the supplier-selection process (Dale, 1994; Yamada, 2001). Consequently, ISO 9001 certified firms are likely to increase their customer base and market share and, therefore, sales. These coupled with internal-process improvements could lead to improvements in overall performance.

In the current competitive environment many firms are seeking ISO 9001:2008 certification to improve their internal business processes for competitive advantage. Conceptually, the balancedscorecard framework would suggest that improvements to internal processes could lead to enhanced performance. Given that certification to ISO 9001 is evidence of improvements to the quality management system driving a firm's internal processes, it follows that ISO 9001 certification is associated with increased performance. The balanced-scorecard framework also suggests that customer satisfaction is associated with sales revenue. This is the drive that comes from the firm's external environment. Finally, the balanced-scorecard framework relates improvements to the internal business processes to greater customer satisfaction and consequently better performance. The theories underpinning ISO 9001 certification and the balance scorecard framework suggest the motivation for ISO 9001 certification could be either internal or external or both.

\subsection{Empirical Literature Review}

Riley (2012) noted that all businesses should try to operate efficiently. However, this is particularly important for a growing business. In many markets, a business needs to be at least as efficient as its main competitors in order to be able to compete and survive in the longterm. A more efficient business will produce lower cost goods than competitors and may generate more profit possibly at lower prices. Increasing efficiency will also boost the capacity of a business, assuming there is no change in the number of inputs employed. The capacity of a firm refers to how much a business can produce during a specific period of time. The NAO review looked at what the $\mathrm{BBC}$ is doing to maximise the efficiency of radio production across its Network and Nations radio stations, focusing on the use of cost comparisons for similar programme types within the $\mathrm{BBC}$ stations and with commercial competitors, the BBC's efficiency plans and the BBC's assessment of the impact of efficiency initiatives on performance (Wiseman and Groves, 2007)

When examining railway efficiency, it is helpful to frame the discussion around two distinct (and often separate) railway functions: infrastructure (generally related to assets on and around the track) and operations (generally focused on the train itself and all of the associated functions). For each of these functions, costs (either investment or running) and revenues (either from "the market" or from the government) can be separated. From a public perspective, the height of net subsidies thus depends on the revenues generated by the market and the level of costs of the railway. In order to analyse railway financial performance in more depth, rail experts created 
several railway efficiency performance indicators that measure efficiency from the government, passenger/client, infrastructure manager and train operating company perspectives (Swier, 2012). One of the difficulties with achieving railway efficiency is the challenge for railways and governments to agree on what the right framework is for achieving efficiency. Definitions of efficient railways can vary. For one nation, a railway may be efficient only when it is profitable with minimal public funding. Alternatively, another government may require the railway to support national economic and mobility policies that deviate from the direct business performance of the railway (i.e. wide market coverage (beyond what makes sense from a business standpoint), lower fares (lower than market rate) to improve mobility of citizens, attract mode share to rail (for environmental or road congestion purposes). According to experts, it is thus critical that governments and railways to define goals and objectives of the railways for themselves and then clearly distinguish roles and responsibilities. When benchmarking railways, these goals and roles of the railway (however defined) must be observed and adequately understood (McNulty, 2011).

Pittman (2007) shows that econometric studies by and large show that existing freight railways are operating at levels where there are still economies of density to be achieved. The primary caution against vertical separation is therefore the concern that competing operators would be unable to reach the available economies of density in rail freight hauling due to fragmentation. The deterioration in the railways has been partly a result of lack of sufficient budgetary provision by the Federal Government coupled with poor management by the Nigerian Railways Corporation (NRC). The Federal Government has disproportionately invested and allocation funds to this sector, in favour of the road transport sub-sector. This situation is traceable to government's lip service and lackadaisical approach to addressing the problems facing the NRC (Filani and Adesanya, 2010). The rail transport subsector hardly gets up to one-fifth of the allocation to the transport sector. Indeed, the lack of necessary resources to keep tracks, rolling stocks and maintenance facility in reasonable working condition is said to have produced a serious deterioration of the railway system (Draft National Transport Policy, 2010).

Van Niekerk and Moreira (2002) observe that performance standards of rail transport within SADC have declined due to, among other things, frequent unavailability of appropriate wagons, poor maintenance of tracks, border delays, unpredictable delivery times, and difficulties in obtaining information on wagon and consignment. However, SADC (2006; 2007) notes that the conditions of some rail networks have been improving due to the construction, rehabilitation and maintenance of SADC inter-country regional corridors. This is evident in, for example, Malawi, Mozambique, and Tanzania

\subsection{RESEARCH METHODOLOGY}

This study adopted a descriptive survey design. The target population of this study was the 450 employees of TATA Chemical Magadi Ltd. The study used a sample of 135 employees. The study employed stratified random sampling to identify the 135 respondents. The strata were those of top management, middle management/supervisors and non-managerial employees. Primary data was used to gather information by use of questionnaires. Information was sorted, coded and input into the statistical package for social sciences (SPSS 20) for production of descriptive and inferential statistics. 


\subsection{RESULTS AND DISCUSSION}

\subsection{Basic Information}

\subsubsection{Respondents' Gender}

Results indicate that majority of workers at Tata Chemicals Ltd are males who constitute of 55\% of the respondents while that of women was $45 \%$. This results imply that Tata Chemical is an equal opportunity employer and a gender balanced institution.

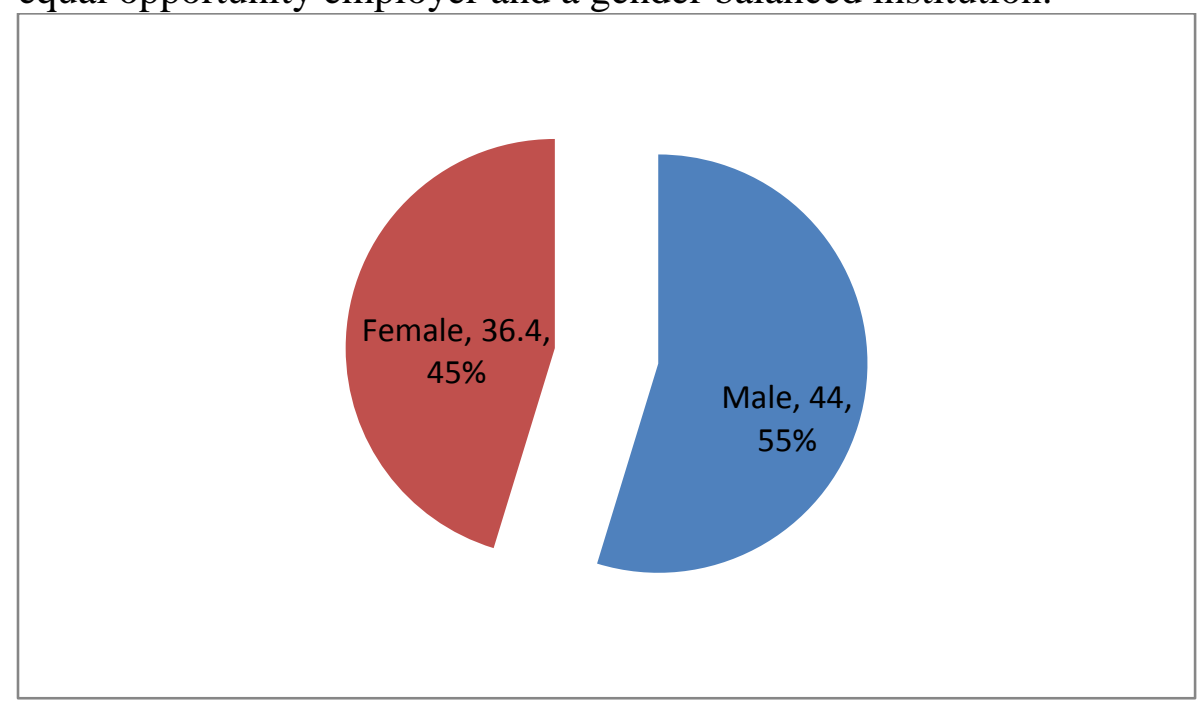

\section{Figure 4.1: Gender of respondents}

\subsubsection{Respondents' Working Experience with Kenya Railways}

Table 4.1 provide results on respondents' working experience with Kenya Railways. Majority of the workers in Tata Chemicals have worked with KRC between 11-15 years. This results imply that Tata Chemicals as a company has been in operation for a long time. Additionally, the results indicate that these two companies have been in associating in business for a long time.

Table 4.1: Respondents' Working Experience with Kenya Railways

\begin{tabular}{lcc}
\hline Period & Frequency & Percent \\
\hline Less than 2 years & 3 & 2.5 \\
3 to 5 years & 8 & 6.6 \\
6 to 10 years & 12 & 9.9 \\
11 to 15 years & 33 & 27.3 \\
16 to 20 years & 12 & 9.9 \\
Over 20 years & 2 & 1.7 \\
\hline
\end{tabular}




\subsubsection{Respondents' Working Experience with Tata Chemicals}

Results in Table 4.2 present the respondents working experience with Tata Chemicals. From the analysis, it is evident that majority of employees have worked in Tata Chemicals for 11 to 15 years. These results imply that Tata Chemicals offers a good working environment because of the long term serving employees. The results also show that there is good management and a good employer-employee relationship throughout the organisation.

Table 4.2: Respondents' Working Experience with Tata Chemicals

\begin{tabular}{lcc}
\hline Period & Frequency & Percent \\
\hline Less than 2 years & 4 & 3.3 \\
3 to 5 years & 13 & 10.7 \\
6 to 10 years & 12 & 9.9 \\
11 to 15 years & 30 & 24.8 \\
16 to 20 years & 11 & 9.1 \\
\hline
\end{tabular}

\subsubsection{Satisfaction with Services Offered by Kenya Railways}

Results in Figure 4.2 presents the level of satisfaction on services offered by Kenya Railways. A majority of $63 \%$ express dissatisfaction on the services offered by KRC. These results imply that the KRC services to Tata Chemicals are very poor and do not meet the expectations of the company. Further, the services of Kenya Railways are inefficient as they reduce the mobility of goods transportation and reduce economic development. These results support those of Pittman (2007) who states that efficient means of transportation stimulates economic development by increasing the mobility of workers commuting from one place to the other and products being transported between producers and consumers.

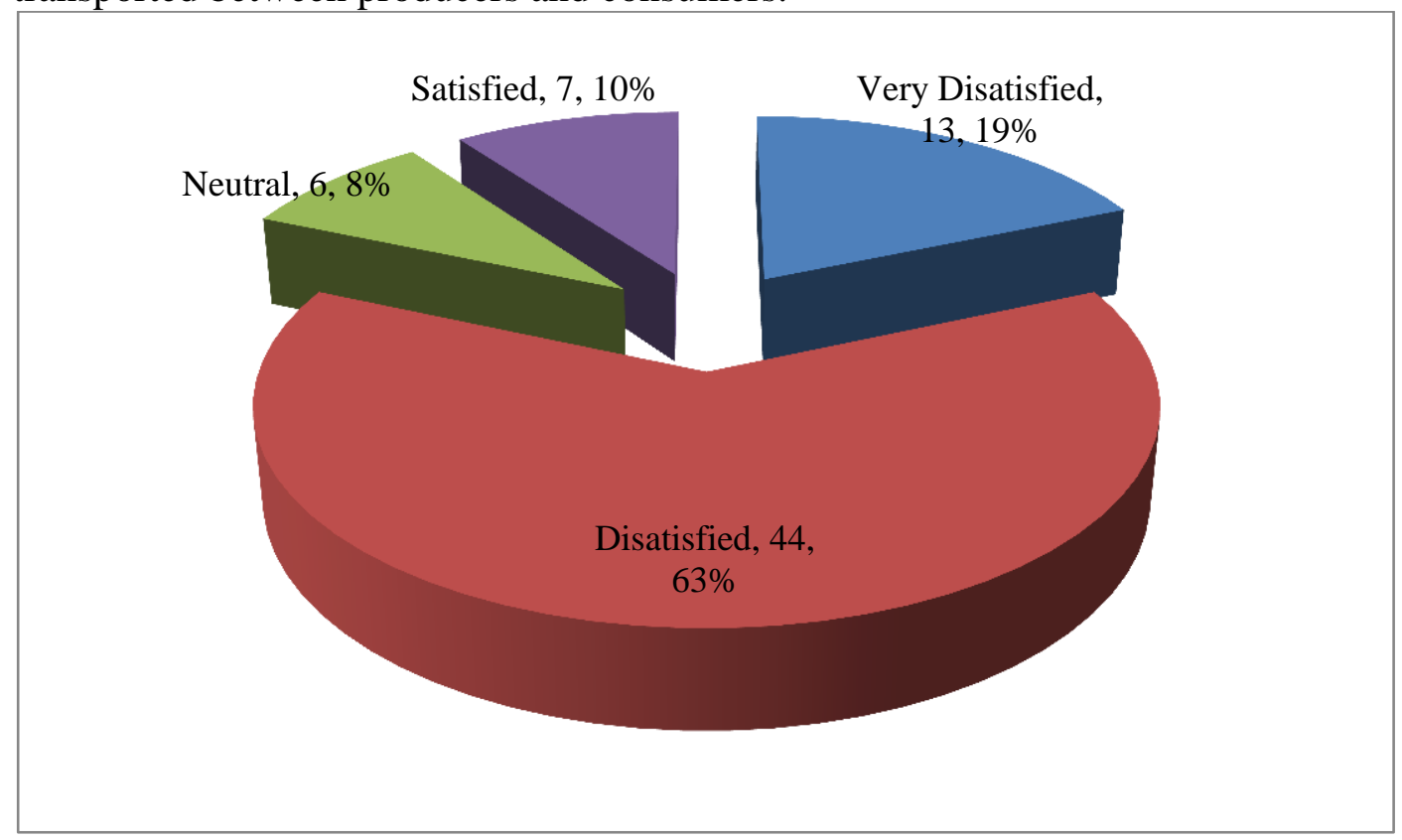




\section{Figure 4.2: Degree of Satisfaction on Kenya Railways Services}

\subsection{Descriptive Statistics}

This section presents the descriptive results where the effects of railway network inefficiencies on the operation of Tata Chemicals are measured.

\subsubsection{Performance of Tata Chemicals}

Results on Table 4.4 shows that inefficiency of KRC has affected the performance of Tata Chemicals as indicated by agreed response rate of $70 \%$. KRC inefficiency to a great extent has caused poor customer satisfaction which affects performance of the company as supported by $60 \%$ agreed responses. Seventy nine percent of the respondents indicate that due to KRC inefficiency the production level have affected performance of Tata Chemicals Ltd. Further results indicate that lack of maintaining sales target, to an extent, led to poor performance of Tata Chemicals as supported by $61 \%$ respondents. Responses from the survey indicated that efficiency of Tata Chemicals Magadi to a great extent affects performance of the company as supported by $80 \%$ agreed responses. These results imply that Tata Chemicals consider efficiency within the company as a significant impact on its performance. Additionally, inefficiency of KRC has affected the customer satisfaction, production levels and sales targets of Tata Chemicals which generally affects the performance of the company. .

Table 4.1: Performance

\begin{tabular}{llllllll}
\hline Statement & $\begin{array}{l}\text { Not at } \\
\text { all }\end{array}$ & $\begin{array}{l}\text { Small } \\
\text { Extent }\end{array}$ & Fairly & $\begin{array}{l}\text { Modera } \\
\text { te } \\
\text { Extent }\end{array}$ & $\begin{array}{l}\text { Great } \\
\text { Extent }\end{array}$ & Mean & $\begin{array}{l}\text { Std. } \\
\text { Dev. }\end{array}$ \\
\hline $\begin{array}{l}\text { Inefficiency of KRC has } \\
\text { affected the performance of }\end{array}$ & $8.60 \%$ & $11.40 \%$ & $10.00 \%$ & $54.30 \%$ & $15.70 \%$ & 3.57 & 1.149 \\
TCML & & & & & & \\
KRC inefficiency has \\
caused poor customer \\
satisfaction which affects \\
performance
\end{tabular}




\subsubsection{Production Targets and Performance}

Results on Table 4.5 shows that due to KRC inefficiency the production levels of Tata Chemicals has declined in the recent past to a great extent as indicated by $73 \%$ agreed responses. Eighty seven percent of the respondents indicated that due to KRC inefficiency Tata Chemicals has been affected by competition, while another $80 \%$ indicate that KRC inefficiency has affected the production of Tata Chemicals which have fallen below budgeted levels. Kenya Railways inefficiency has lowered the capacity of business in Tata Chemicals as supported by $70 \%$ responses. Inefficiencies of Kenya Railways, to a great extent, have forced Tata chemical to make investment in rail which is not a core business for the company as indicated by $69 \%$ responses. These findings agree with those of Honeywell (2011) who indicated that in today's competitive market, every mineral processing facility is striving to operate their plant assets at a maximum capacity or efficiency level all the time. However, decreased production rates, delays and unplanned shutdowns are regular occurrences which affect production utilization.

Table 4.2: Production Targets and Performance

\begin{tabular}{|c|c|c|c|c|c|c|c|}
\hline Statement & $\begin{array}{c}\text { Not at } \\
\text { all }\end{array}$ & $\begin{array}{c}\text { Small } \\
\text { Extent }\end{array}$ & $\begin{array}{c}\text { Fairl } \\
\mathbf{y}\end{array}$ & $\begin{array}{c}\text { Moderate } \\
\text { Extent }\end{array}$ & $\begin{array}{c}\text { Great } \\
\text { Extent }\end{array}$ & Mean & Std. Dev \\
\hline $\begin{array}{l}\text { Due to KRC inefficiency the } \\
\text { production level have } \\
\text { declined in the recent past }\end{array}$ & $8.60 \%$ & $5.70 \%$ & $\begin{array}{c}11.40 \\
\%\end{array}$ & $55.70 \%$ & $18.60 \%$ & 3.7 & 1.108 \\
\hline $\begin{array}{l}\text { Due to KRC inefficiency Tata } \\
\text { Chemicals has been affected } \\
\text { by competition }\end{array}$ & $4.30 \%$ & $4.30 \%$ & $\begin{array}{c}4.30 \\
\%\end{array}$ & $71.40 \%$ & $15.70 \%$ & 3.9 & 0.871 \\
\hline $\begin{array}{l}\text { Due to KRC inefficiency the } \\
\text { production level have fallen } \\
\text { below budgeted levels }\end{array}$ & $4.30 \%$ & $4.30 \%$ & $\begin{array}{c}11.40 \\
\%\end{array}$ & $51.40 \%$ & $28.60 \%$ & 3.96 & 0.984 \\
\hline $\begin{array}{l}\text { Kenya Railways inefficiency } \\
\text { has lowered the capacity of } \\
\text { business in Tata Chemicals }\end{array}$ & $8.60 \%$ & $4.30 \%$ & $\begin{array}{c}17.10 \\
\%\end{array}$ & $51.40 \%$ & $18.60 \%$ & 3.67 & 1.1 \\
\hline $\begin{array}{l}\text { Inefficiencies of Kenya } \\
\text { Railways has forced Tata } \\
\text { chemical to make investment } \\
\text { in rail which is not a core } \\
\text { business for the company }\end{array}$ & $10.00 \%$ & $7.10 \%$ & $\begin{array}{c}14.30 \\
\%\end{array}$ & $54.30 \%$ & $14.30 \%$ & 3.56 & 1.137 \\
\hline
\end{tabular}

\subsubsection{Customer Satisfaction and Performance}

Eighty three percent of the respondents indicate that Tata chemicals have on various occasions failed to deliver on time due to delays from Kenya Railways Cargo which has led to loss of customers. Eighty five percent of the respondents indicate that there is a lot of theft of cargo enroute to various destinations leading to customers' dissatisfaction. Additionally, eighty five percent responses shows that to a great extent Tata chemicals have experienced customers 
switching to competitors as a result of $\mathrm{KRC}$ inefficiencies while another $81 \%$ indicate that the numbers of complains have been on the rise due to KRC inefficiencies. These results imply that poor customer satisfaction such as delays in delivery, theft of goods on transit has led to losses in Tata Chemicals Magadi. These findings support those of Van Niekerk and Moreira (2002) who observe that decline in performance standards of rail transport within SADC have declined due to poor maintenance of tracks, border delays which causes unpredictable delivery which in turn inconveniences customers leading to their dissatisfaction.

Table 4.3: Customer Satisfaction and Performance

\begin{tabular}{|c|c|c|c|c|c|c|c|}
\hline Statement & $\begin{array}{l}\text { Not at } \\
\text { all }\end{array}$ & $\begin{array}{l}\text { Small } \\
\text { Extent }\end{array}$ & Fairly & $\begin{array}{l}\text { Moder } \\
\text { ate } \\
\text { Extent }\end{array}$ & $\begin{array}{l}\text { Great } \\
\text { Extent }\end{array}$ & Mean & $\begin{array}{l}\text { Std. } \\
\text { Dev }\end{array}$ \\
\hline $\begin{array}{l}\text { Tata chemicals has on various } \\
\text { occasions failed to deliver on } \\
\text { time due to delays from Kenya } \\
\text { Railways }\end{array}$ & $8.60 \%$ & $2.90 \%$ & $5.70 \%$ & $48.60 \%$ & $34.30 \%$ & 3.97 & 1.142 \\
\hline $\begin{array}{l}\text { Cargo delays by Kenya railways } \\
\text { has led to loss of many customers }\end{array}$ & $10.00 \%$ & $2.90 \%$ & $1.40 \%$ & $45.70 \%$ & $40.00 \%$ & 4.03 & 1.204 \\
\hline $\begin{array}{l}\text { There is a lot of theft of cargo en- } \\
\text { route to various destinations } \\
\text { leading to customers } \\
\text { dissatisfaction }\end{array}$ & $5.70 \%$ & $2.90 \%$ & $10.00 \%$ & $71.40 \%$ & $10.00 \%$ & 3.77 & 0.887 \\
\hline $\begin{array}{l}\text { Tata chemicals has experienced } \\
\text { customers switching to } \\
\text { competitors as a result of KRC } \\
\text { inefficiencies }\end{array}$ & $4.30 \%$ & $1.40 \%$ & $8.60 \%$ & $80.00 \%$ & $5.70 \%$ & 3.81 & 0.748 \\
\hline $\begin{array}{l}\text { The numbers of complains have } \\
\text { been on the rise due to KRC } \\
\text { inefficiencies }\end{array}$ & $4.30 \%$ & $0.00 \%$ & $8.60 \%$ & $77.10 \%$ & $10.00 \%$ & 3.89 & 0.753 \\
\hline
\end{tabular}

\subsubsection{Sales Target and Performance}

Results in Table 4.7 indicate that KRC inefficiencies has reduced our sales targets for salt products as supported by $94 \%$ responses while another $81 \%$ indicate that KRC inefficiencies have reduced the sales targets for sodium bicarbonate. From the results, $82 \%$ of KRC inefficiencies have reduced our sales targets for water purifier products. Ninety four percent of the responses indicate that KRC inefficiencies have reduced the sales targets for cement products in Tata Chemicals while another 96\% indicate that KRC inefficiencies have reduced the sales targets for farm input such as fertilizers and pesticides. These results imply that due to the inefficiency of Kenya Railway Corporation, projection in sales of Tata Chemicals has been challenged. 
Table 4.4: Sales Targets

\begin{tabular}{|c|c|c|c|c|c|c|c|}
\hline Statement & $\begin{array}{c}\text { Not at } \\
\text { all }\end{array}$ & $\begin{array}{c}\text { Small } \\
\text { Extent }\end{array}$ & $\begin{array}{c}\text { Fairl } \\
\mathbf{y}\end{array}$ & $\begin{array}{l}\text { Moderat } \\
\text { e Extent }\end{array}$ & $\begin{array}{c}\text { Great } \\
\text { Extent }\end{array}$ & Mean & $\begin{array}{l}\text { Std. } \\
\text { Dev }\end{array}$ \\
\hline $\begin{array}{l}\text { KRC inefficiencies has reduced our } \\
\text { sales targets for salt product }\end{array}$ & $4.30 \%$ & $1.40 \%$ & $\begin{array}{c}0.00 \\
\%\end{array}$ & $54.30 \%$ & $40.00 \%$ & 4.24 & 0.892 \\
\hline $\begin{array}{l}\text { KRC inefficiencies have reduced } \\
\text { our sales targets for sodium } \\
\text { bicarbonate }\end{array}$ & $4.30 \%$ & $14.30 \%$ & $\begin{array}{c}0.00 \\
\%\end{array}$ & $45.70 \%$ & $35.70 \%$ & 3.94 & 1.153 \\
\hline $\begin{array}{l}\text { KRC inefficiencies have reduced } \\
\text { our sales targets for water purifier } \\
\text { products. }\end{array}$ & $0.00 \%$ & $8.60 \%$ & $\begin{array}{c}8.60 \\
\%\end{array}$ & $45.70 \%$ & $37.10 \%$ & 4.11 & 0.894 \\
\hline $\begin{array}{l}\text { KRC inefficiencies have reduced } \\
\text { our sales targets for cement } \\
\text { products. }\end{array}$ & $4.30 \%$ & $1.40 \%$ & $\begin{array}{c}0.00 \\
\%\end{array}$ & $75.70 \%$ & $18.60 \%$ & 4.03 & 0.798 \\
\hline $\begin{array}{l}\text { KRC inefficiencies have reduced } \\
\text { our sales targets for Farm input } \\
\text { such as fertilizers and pesticides }\end{array}$ & $4.30 \%$ & $0.00 \%$ & $\begin{array}{c}0.00 \\
\%\end{array}$ & $71.40 \%$ & $24.30 \%$ & 4.11 & 0.79 \\
\hline
\end{tabular}

\subsubsection{Equipment Utilization and Performance}

Results on Table 4.8 indicate that KRC inefficiencies have led to a reduction in operating capacities of mining equipment as supported by $77 \%$ responses. Ninety four percent of the responses indicate that $\mathrm{KRC}$ inefficiencies have led to a reduction in operating capacities of fertilizers manufacturing equipment. Further results shows that KRC inefficiencies has led to a reduction in operating capacities of pesticides manufacturing equipment as supported by $73 \%$ response rate. Seventy seven percent of KRC inefficiencies has led to a reduction in operating capacities of soda ash manufacturing equipment while another $66 \%$ indicate that KRC inefficiencies has led to a reduction in operating capacities of salt pans manufacturing equipment. These results imply that inefficiencies of KRC has led to Tata Chemicals to have a reduction of operating activities of equipment in mining, fertilisers, soda ash and pesticides manufacturing which significantly affects the performance of the company. 
Table 4.5: Equipment Utilization

\begin{tabular}{|c|c|c|c|c|c|c|c|}
\hline Statement & $\begin{array}{c}\text { Not } \\
\text { at all }\end{array}$ & $\begin{array}{c}\text { Small } \\
\text { Extent }\end{array}$ & Fairly & $\begin{array}{l}\text { Moder } \\
\text { ate } \\
\text { Extent }\end{array}$ & $\begin{array}{c}\text { Great } \\
\text { Extent }\end{array}$ & Mean & $\begin{array}{c}\text { Std.De } \\
\text { v. }\end{array}$ \\
\hline $\begin{array}{l}\text { KRC inefficiencies have led to a } \\
\text { reduction in operating capacities of } \\
\text { mining equipment }\end{array}$ & $\begin{array}{c}8.60 \\
\%\end{array}$ & $10.00 \%$ & $4.30 \%$ & $51.40 \%$ & $25.70 \%$ & 3.76 & 1.197 \\
\hline $\begin{array}{l}\text { KRC inefficiencies has led to a } \\
\text { reduction in operating capacities of } \\
\text { fertilizers manufacturing equipment }\end{array}$ & $\begin{array}{c}4.30 \\
\%\end{array}$ & $1.40 \%$ & $0.00 \%$ & $45.70 \%$ & $48.60 \%$ & 4.33 & 0.912 \\
\hline $\begin{array}{l}\text { KRC inefficiencies has led to a } \\
\text { reduction in operating capacities of } \\
\text { pesticides manufacturing equipment }\end{array}$ & $\begin{array}{c}0.00 \\
\%\end{array}$ & $18.60 \%$ & $8.60 \%$ & $41.40 \%$ & $31.40 \%$ & 3.86 & 1.067 \\
\hline $\begin{array}{l}\text { KRC inefficiencies has led to a } \\
\text { reduction in operating capacities of } \\
\text { soda ash manufacturing equipment }\end{array}$ & $\begin{array}{c}0.00 \\
\%\end{array}$ & $18.60 \%$ & $4.30 \%$ & $28.60 \%$ & $48.60 \%$ & 4.07 & 1.133 \\
\hline $\begin{array}{l}\text { KRC inefficiencies has led to a } \\
\text { reduction in operating capacities of } \\
\text { salt pans manufacturing equipment }\end{array}$ & $\begin{array}{c}15.70 \\
\%\end{array}$ & $18.60 \%$ & $0.00 \%$ & $28.60 \%$ & $37.10 \%$ & 3.53 & 1.53 \\
\hline
\end{tabular}

\subsection{Inferential Statistics}

Inferential analysis was conducted to generate correlation results, model of fitness, and analysis of the variance and regression coefficients.

\subsubsection{Pearson's Bivariate Correlation Analysis}

The Pearson's Bivariate analysis sought to find whether there was any significant relationship between the variables. The results of this relationship are presented in Table 4.9. Results shows that production and equipment utilization were significant in determining performance of Tata Chemicals as their value of 0.000 and 0.004 respectively was a value lower than the conventional $\mathrm{p}$ value 0.05 . The results further show that the variables besides sales target had positive correlation that is production (0.781), customer satisfaction (0.181) and equipment utilization (0.342). This means that an increase in either of the variables positively influences performance while a decrease in the same negatively affects performance. 
Table 4.6: Bivariate Correlation Analysis

\begin{tabular}{|c|c|c|c|c|c|c|}
\hline Variable & & $\begin{array}{c}\text { Performa } \\
\text { nce }\end{array}$ & $\underset{n}{\text { Productio }}$ & $\begin{array}{c}\text { Customer } \\
\text { satisfaction }\end{array}$ & $\begin{array}{c}\text { Sales } \\
\text { Target }\end{array}$ & $\underset{\mathbf{t}}{\text { Equipmen }}$ \\
\hline \multirow[t]{2}{*}{ Performance } & $\begin{array}{l}\text { Pearson } \\
\text { Correlation }\end{array}$ & 1 & & & & \\
\hline & Sig. (2-tailed) & & & & & \\
\hline \multirow[t]{2}{*}{ Production } & $\begin{array}{l}\text { Pearson } \\
\text { Correlation }\end{array}$ & 0.781 & 1 & & & \\
\hline & Sig. (2-tailed) & 0.000 & & & & \\
\hline \multirow[t]{2}{*}{$\begin{array}{l}\text { Customer } \\
\text { satisfaction }\end{array}$} & $\begin{array}{l}\text { Pearson } \\
\text { Correlation }\end{array}$ & 0.181 & -0.13 & 1 & & \\
\hline & Sig. (2-tailed) & 0.133 & 0.283 & & & \\
\hline \multirow[t]{2}{*}{ Sales Target } & $\begin{array}{l}\text { Pearson } \\
\text { Correlation }\end{array}$ & -0.068 & -0.38 & 0.119 & 1 & \\
\hline & Sig. (2-tailed) & 0.575 & 0.001 & 0.326 & & \\
\hline \multirow[t]{2}{*}{ Equipment } & $\begin{array}{l}\text { Pearson } \\
\text { Correlation }\end{array}$ & 0.342 & -0.012 & 0.134 & 0.237 & 1 \\
\hline & Sig. (2-tailed) & 0.004 & 0.919 & 0.268 & 0.049 & \\
\hline
\end{tabular}

\subsubsection{Regression Analysis}

Table 4.7 shows fitness of the regression model in explaining the study phenomena; production levels, customer satisfaction, sales targets and equipment. This is supported by coefficient of determination also known as the $\mathrm{R}$ square of $90 \%$. This means that production levels, customer satisfaction, sales targets and equipment explain $90 \%$ of the variations in the dependent variable which is performance of Tata Chemicals Magadi Ltd. This results further means that the model applied to link the relationship of the variables was satisfactory.

Table 4.7: Model Fitness

\begin{tabular}{lc}
\hline Indicator & Coefficient \\
\hline R & 0.903 \\
R Square & 0.815 \\
Std. Error of the Estimate & 0.19799 \\
\hline
\end{tabular}

Statistically, the $\mathrm{p}$ value indicates the relationship of independent and dependent variable. If the significance number found is less than the critical value also known as the probability value (p) which is statistically set at 0.05 , then the model would be statistically significant in explaining the relationship; else the model would be regarded as not significant. Results in Table 4.11 show the analysis of variance where the analysis shows that the overall model was statistically significant. Further, the results imply that the independent variables are good predictors of 
performance. This was supported by an F statistic of 71.69 and the reported p value (0.000) which was less than the conventional probability of 0.05 significance level.

Table 4.7: Analysis of Variance

\begin{tabular}{lccccc}
\hline Indicator & $\begin{array}{c}\text { Sum of } \\
\text { Squares }\end{array}$ & Df & $\begin{array}{c}\text { Mean } \\
\text { Square }\end{array}$ & F & Sig. \\
\hline Regression & 11.241 & 4 & 2.81 & 71.695 & 0.000 \\
Residual & 2.548 & 65 & 0.039 & & \\
\hline
\end{tabular}

Regression of coefficients results in Table 4.12 shows that there is a positive relationship between production, customer satisfaction, sales target, equipment utilization and performance of Tata Chemicals Magadi Ltd. These was supported by beta coefficients of 1.444, 0.243, 0.308 and 0.368 respectively. These results shows that a unit change in either of the variables will definitely lead to a change in performance of the company. The results from the table below also indicate that production, customer satisfaction and equipment utilization were statistically significant in measuring performance as they had a probability of 0.000 while sales target had a probability of 0.005 which is lower than the probability conventional of 0.05 . These results imply that inefficiencies of any of the mentioned variables; production, customer satisfaction and equipment utilization causes delivery delays, poor service to the clients of Tata Chemicals Magadi Ltd which affects the performance of the company. These findings support those of Olievschi (2012) who suggest that the major internal factors are the poor quality of rolling stock inducing low availability of wagons or lack of locomotives, and the poor quality of infrastructure generating speed restrictions, unpredictability of arrival, low safety and many derailments. These factors make the railways an uninteresting service provider for clients.

Table 4.7: Regression of Coefficients

\begin{tabular}{lcccc}
\hline Indicator & Beta & Std. Error & $\mathbf{t}$ & Significant \\
\hline Constant & -5.783 & 0.726 & -7.97 & 0.000 \\
Production & 1.444 & 0.095 & 15.142 & 0.000 \\
Customer Satisfaction & 0.243 & 0.056 & 4.377 & 0.000 \\
Sales Target & 0.308 & 0.107 & 2.888 & 0.005 \\
Equipment & 0.368 & 0.073 & 5.055 & 0.000 \\
\hline
\end{tabular}

\subsection{CONCLUSIONS AND RECOMMENDATIONS}

\subsection{Conclusions}

Railway networks are an important mode of long distance transportation of raw materials among other production equipment. Poor performance in Tata Chemicals is partly attributed to inefficiency of Kenya Railways Company. The results from this analysis confirm the importance of having good structures and proper technical progress that the country requires to enhance efficiency in the railway transport. Lack of efficiency in the Railway network in Kenya affects 
the production levels of companies which rely on the same for delivery of goods. Additionally, lack of infrastructure may lead to significant losses in productivity in both the short and long run. Further conclusions made were that railway networks cause service ineffectiveness of Tata Chemicals Ltd as a result of theft in goods, delays in service delivery to their customers. Poor performance in transport services can be attributed to either poor technical efficiency or poor service effectiveness or a combination of both which affects customers who are in the receiving end. From the results it is evident to conclude that inefficiency in the railway network causes companies not to meet their sales targets. The ineffectiveness of the rail system has been linked with corruption given the high losses incurred by customers whose goods end up stolen or misplaced during transit. Additional results leads to the conclusion that inefficiency in the rail network, causes a negative effect on the equipment utilization which affects the subsequent manufacturing operations.

\subsection{Recommendations}

This study provides recommendations to the management of Kenya Railway Corporation, Tata Chemicals Magadi Ltd and the government.

The management of KRC has to maintain rails network by constantly inspecting the same to determine whether further maintenance is required, plan for replacement parts, labor among other costs and improve reliability of the railway transport system. It is important for KRC to invest in the railway network by managing the rails and technology which will increase its efficiency. The government should also allocate some annual budget to the Kenya Railways Corporation to provide efficient means of transporting freight among cities.

Recommendations to Tata Chemicals Magadi Ltd are that the company should exercise stronger leadership to enhance long term planning and disaster management to avoid loss in customers and manage its efficiency. Additionally, to avoid delays in delivery, the company should come up with strategies that will curb this challenge. For instance, the management of Tata Chemicals may decide to engage in ordering of raw materials, equipment among other items that assist them in operation a little bit earlier to ease their service delivery to their clients.

\section{REFERENCES}

Pittman, R. (2007). Options for restructuring the state-owned monopoly railway. In Dennis,S. M. and Tally, W. K. (Eds). Research in transportation economics. Volume 20: RailroadEconomics (pp. 179-98). Oxford: Elsevier.

Graham, D., Couto, A., Adeney, W., \& Glaister, S. (2003). Economies of scale and density in urban rail transport: Effects on productivity. Transportation Research Part E. Logistics and Transportation Review, 39(6): 443-58.

Swier, J. (2012). Business Case for Rail Transport Captured in a Single Model, Utrecht. 
International Journal of Business Strategies

ISSN 2519- 0857 (Online)

Vol.1, Issue 1 No.1, pp 26 - 43, 2016

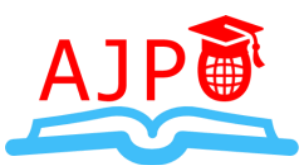

www.ajpojournals.org

World Bank. (2005). Meeting the challenges of Africa's development: A World Bank Group Action Plan. Available from: http://siteresources.worldbank.org/INTAFRICA/Resources/aap_final.pdf.

Wu, J., \& Nash C. (2000). Railway reform in China, Transport Reviews, Vol. 20, 2000, pp. 2548. 